\title{
PERSEPSI PESERTA BPJS KESEHATAN TERHADAP PROGLAM PENGELOLAAN PENYAKIT KRONIS DI PUSKESMAS I DENPASAR BARAT DAN PUSKESMAS II DENPASAR TIMUR
}

\author{
Putu Inok Puspaeni*, Desak Putu Yuli Kurniati, Putu Ayu Indrayathi \\ Program Studi Kesehatan Masyarakat Fakultas Kedokteran Universitas Udayana \\ *E-mail: inok_puspaeni@yahoo.co.id
}

\begin{abstract}
ABSTRAK
Pada era Jaminan Kesehatan Nasional salah satu upaya yang dilaksanakan untuk menanggulangi penyakit kronis adalah Prolanis. Puskesmas se-Kota Denpasar telah melaksanakan program prolanis tetapi terdapat perbedaan rasio kunjungan peserta prolanis tertinggi dan terendah. Tujuan penelitian ini untuk mengetahui gambaran persepsi peserta BPJS Kesehatan terhadap program pengelolaan penyakit kronis di Puskesmas I Denpasar Barat dan Puskesmas II Denpasar Timur. Penelitian ini merupakan penelitian deskriptif kualitatif dengan purposive sampling menggunakan metode wawancara mendalam dan focus group discusion. Penelitian ini dilaksanakan di Puskesmas I Denpasar Barat dan Puskesmas II Denpasar Timur dari bulan Mei-Juni 2017. Informan penelitian berjumlah sembilan belas orang yang terdiri dari kepala puskesmas, pemegang program prolanis dan peserta BPJS Kesehatan yang tergabung dalam kelompok prolanis. Hasil penelitian menunjukkan peserta prolanis di Puskesmas I Denpasar Barat merasa rentan terkena penyakit diabetes/ hipertensi dan dampak penyakit tersebut menimbulkan ketakutan dan kecemasan pada peserta karena efek keseriusan penyakit sudah dilihat/ dirasakan. Besarnya manfaat yang dirasakan mampu menutupi hambatan yang dialami, selain itu dukungan teman dan rasa kekeluargaan meningkatkan partisipasi peserta prolanis. Maka dari itu puskesmas yang rasio kunjungan prolanis rendah perlu mengundang keluarga yang menderita diabetes/ hipertensi untuk memberikan testimoni.
\end{abstract}

Kata Kunci : Prolanis, Persepsi, Puskesmas

\begin{abstract}
In the era of National Health Insurance, one of the efforts undertaken to tackle chronic illness is Prolanis. Health centers throughout Denpasar have implemented prolanis programs but there are differences in the ratio of visits of the highest and lowest prolanis participants. The purpose of this study was to determine the description of BPJS Health participants' perceptions of chronic disease management programs in Puskesmas I Denpasar Barat and Puskesmas II Denpasar Timur. This research is a qualitative descriptive study with purposive sampling using indepth interviews and focus group discussion methods. The research was conducted at the Health Center I of West Denpasar and Health Center II of East Denpasar from May-June 2017. The informants of the study consisted of nineteen people consisting of the head of the puskesmas, the prolanist program holder and BPJS Health participants who were members of the prolanist group. The results showed prolanis participants in Puskesmas I Denpasar Barat felt vulnerable to diabetes / hypertension and the impact of the disease caused fear and anxiety in participants because the seriousness of the disease had been seen / felt. The amount of benefits felt is able to cover the obstacles experienced, in addition to the support of friends and a sense of family to increase participation of prolanist participants. Therefore a puskesmas with a low prolanis visit ratio needs to invite families suffering from diabetes / hypertension to provide testimonials.
\end{abstract}

Keywords: Prolanis, Perception, Puskesmas

\section{PENDAHULUAN}

Penyakit Tidak Menular (PTM) menjadi penyebab utama kematian secara global sekitar $63 \%$ dari seluruh kematian per tahun dan membunuh lebih dari 36 juta orang per tahunnya
(Indrayana \& Palupi, 2014). Menurut profil PTM WHO (2011) di Indonesia tahun 2008 terdapat 582.300 laki-laki dan 481.700 perempuan meninggal karena PTM. 
Menurut surveilan terpadu penyakit (STP) berbasis puskesmas berdasarkan kasus baru tahun 2016 di Kota Denpasar kasus hipertensi menjadi penyakit tertinggi yaitu sebanyak 7458 kasus, peringkat kedua penyakit diare dengan 6742 kasus dan DM sebanyak 3403 kasus (Dinkes Kota Denpasar, 2016).

Pada era Jaminan Kesehatan Nasional BPJS Kesehatan memfokuskan pelayanan kesehatan pada upaya promotif dan preventif. Prolanis merupakan salah satu upaya promotif dan preventif yang dilakukan oleh BPJS Kesehatan selain program penyuluhan kesehatan, imunisasi, keluarga berencana dan skrining kesehatan (BPJS Kesehatan, 2014b).

Puskesmas se- Kota Denpasar telah aktif melakukan progran prolanis, tercatat 11 puskesmas telah bekerja sama dengan BPJS Kesehatan. Namun dalam pelaksanaannya terdapat kesenjangan jumlah kunjungan peserta prolanis yang rutin berkunjung ke puskesmas.

Berdasarkan data primer yang diolah oleh peneliti dari buku kunjungan peserta prolanis di puskesmas se-Kota Denpasar, puskesmas dengan rasio kunjungan peserta prolanis tertinggi terdapat di Puskesmas I Denpasar Barat dari 51 peserta klub prolanis tingkat kehadiran sebesar $92 \%$ dan rasio kunjungan terendah terdapat di Puskesmas II Denpasar Timur dari 30 peserta klub prolanis tingkat kehadiran sebesar 56\%. Berdasarkan hasil wawancara dengan pemegang program di masing-masing puskesmas diketahui peserta prolanis memiliki kisaran umur rata-rata 60 tahun.
Berdasarkan latar belakang tersebut peneliti ingin menggali lebih dalam persepsi peserta BPJS Kesehatan terhadap program prolanis pada puskesmas dengan rasio kunjungan peserta prolanis tertinggi di Puskesmas I Denpasar Barat dan rasio kunjungan peserta prolanis terendah di Puskesmas II Denpasar Timur yang mempengaruhi keikutsertaannya dalam kegiatan prolanis yang diselenggarakan puskesmas yang sangat berpengaruh pada kualitas hidup penderita penyakit kronis dan tingkat keberhasilan program.

\section{METODE}

Penelitian ini merupakan penelitian deskriptif dengan pendekatan kualitatif dengan purposive sampling menggunakan metode wawancara mendalam dan focus group discusion. Penelitian ini dilaksanakan di Puskesmas I Denpasar Barat dan Puskesmas II Denpasar Timur. Analisis data yang digunakan pada penelitian ini adalah analisis tematik.

\section{HASIL}

Informan penelitian berjumlah sembilan belas orang yang terdiri dari kepala puskesmas, pemegang program prolanis dan peserta BPJS Kesehatan yang tergabung dalam klub prolanis di Puskesmas I Denpasar Barat dan Puskesmas II Denpasar Timur.

\section{Persepsi Peserta BPJS Kesehatan Terhadap Kerentanan Penyakit Diabetes Mellitus/ Hipertensi}

Dari hasil penelitian persepsi kerentanan peserta prolanis terhadap penyakit diabetes/ hipertensi menunjukkan, persepsi kerentanan yang diungkapkan peserta prolanis di 
Puskesmas I Denpasar Barat lebih banyak karena riwayat keluarga yang menderita diabetes/ hipertensi.

"Ya, bapak yang hipertensi tapi waktu muda dulu semasa sekolah sampai SMF tensi saya rendah sampai sering pingsan. Trus saya juga rajin sekali ikut senam dik tiap minggu ikut senam di studio senam, pas ada pemeriksaan dari dokter saya dilarang ikut senam aerobik karena dicek tensinya 150. Saya tidak menyangka kena hipertensi, mungkin karena keturunan dik." (HT-07)

Sedangkan persepsi kerentanan yang diungkapkan peserta prolanis di Puskesmas II Denpasar timur dominan karena riwayat pola makan yang beresiko

"Kebiasaan dulu suka minum yang manismanis. Saya suka sekali minuman seperti fanta, teh botol kalau buat teh juga harus yang manis. Karena waktu itu 3 hari berturut-turut saya minum itu selama kerja seminggunya saya sering kencing terus iseng cek di apotek dibilang tinggi gula darahnya." (DM-16)

\section{Persepsi Peserta BPJS Kesehatan} Terhadap Tingkat Keseriusan Penyakit Diabetes Mellitus/ Hipertensi

Berdasarkan hasil penelitian persepsi tingkat keseriusan penyakit menunjukkan dampak keseriusan penyakit diabetes/ hipertensi di Puskesmas I Denpasar Barat condong pada dampak yang sudah peserta rasakan/ lihat secara langsung.

"Iya, adik saya juga kena DM kakinya luka susah sembuh sampai bongkang (borok)." (DM-04)

Sedangkan persepsi keseriusan di Puskesmas II Denpasar Timur lebih banyak berdampak pada organ-organ tubuh.

“Takutnya kena komplikasi dik, kalau komplikasi semua organ bisa kena bisa ke ginjal jadinya harus cuci darah terus kena pankreas hatinya yang rusak. Jadi harus rajin olah raga sama jaga pola makan." (DM-14)

3. Persepsi Manfaat yang diperoleh Peserta BPJS Kesehatan selama Mengikuti Program Prolanis

Penelitian ini menunjukkan manfaat yang dirasakan peserta prolanis di Puskesmas I Denpasar Barat tidak hanya adanya perubahan pada kontrol gula darah atau perubahan pada fisiknya tapi lebih pada manfaat sosial.

"Kawan-kawan disini sudah seperti keluarga, kalau saya sudah diabetes obat yang dikasi apotek pasti obat tapi disini bisa ngobrol dengan teman-teman sharing berbagai informasi sudah obat buat saya, saya tidak merasa sendirian sakit." (DM-02)

Sedangkan manfaat yang dirasakan peserta prolanis di Puskesmas II Denpasar Timur lebih pada dampak kesehatan individu yaitu pada perubahan gula darah dan kurang merasakan adanya dukungan sosial dari peserta lainnya.

"Ya terasa sekali untuk mengetahui perkembangan gula darahnya, jadi kalau di cek gulanya tinggi saya bisa tanggulangi dari pola makan saya. Karena dirumah saya tidak punya alatnya, jadi saya rajin ke puskesmas untuk cek. Sekarang gula darahnya sudah normal" (DM-10)

4. Hambatan yang dialami Peserta BPJS Kesehatan selama Mengikuti Program Prolanis

Berdasarkan hasil penelitian terhadap persepsi hambatan peserta 
prolanis selama mengikuti kegiatan prolanis menunjukkan bahwa peserta prolanis di Puskesmas I Denpasar Barat mengalami hambatan karena hambatan individu/ peserta sendiri seperti adanya kegiatan keagamaan atau kesibukan mengurus cucu.

"Tidak hadir paling repot ngajak cucu, karena pagi-pagi harus antar dia kesekolah pas ibunya bisa antar saya bisa sampai siang disini kalau tidak kan harus cepet-cepet pulang kadang kalau waktunya mepet saya tidak ikut senam." (HT-07)

Hambatan yang dialami peserta prolanis di Puskesmas II Denpasar Timur lebih bervariasi, selain hambatan tersebut berasal dari individu/ peserta prolanis hambatan yang dirasakan terkait jadwal pelaksanaan senam yang dilaksanakan puskesmas tidak konsisten dan dua dari delapan informan menyatakan kesulitan dalam mengikuti kegiatan prolanis karena berbenturan dengan pekerjaan.

"Kalau kegiatan edukasi saya jarang hadir tapi senamnya saya usahakan datang, tapi kalau itu berbenturan dengan pekerjaan, saya tidak hadir karena saya kerja jam 08.00."(DM-10)

"Dulu dari puskesmas jadwalnya minggu kedua sama minggu keempat. Terus pas minggu itu ada rainan katanya senamnya ditiadakan. Sekarang jadwalnya satu minggu sekali jadi kalau ketemu rainan tidak senam lagi. Kacau jadi jadwalnya. Jadinya malas datang." ( DM-13)

\section{Cues to action Peserta Prolanis dalam}

\section{Mengikuti Kegiatan Prolanis}

Dari hasil penelitin terhadap isyarat untuk bertindak dari peserta prolanis dalam mengikuti kegiatan prolanis adalah sikap petugas yang ramah, dukungan teman, serta riwayat kesehatan individu yang terkena stroke. Namun terdapat perbedaan isyarat bertindak antara dua puskesmas. Perbedaannya adalah dorongan yang diberikan peserta lainnya di Puskesmas II Denpasar Timur belum mendapat respon yang baik sehingga mempengaruhi tingkat partisipasi peserta prolanis.

"Ada sih yang nanyain itu kenapa tidak datang, bilang aja sibuk. Anggotanya tidak kompak males datang." (DM-09)

Selain itu untuk meningkatkan partisipasi peserta, pemegang program di Puskesmas I Denpasar Barat telah membuat inovasi untuk meningkatkan minat peserta prolanis. Hal ini belum diterapkan Puskesmas II Denpasar Timur.

"Tahun 2014 saya buat biar anggotanya rajin datang dengan memberikan doorprise atau undianlah biar mereka semangat dan tertarik untuk datang." (PP-01)

"Kalau melakukan inovasi buat menarik peserta datang belum sih. Agak susah dik, klub disini juga baru terbentuk terus kesadaran masyarakat masih kurang jadi cuma sebatas menginformasikan saja ke pesertanya." (PP-02)

"Inovasi belum ada tapi dengan kegiatan senam sama edukasi saja mereka sudah mau datang. Tapi kedepannya akan saya rencanakan kegiatan lain." (KP-02)

\section{DISKUSI}

1. Persepsi Peserta BPJS Kesehatan Terhadap Kerentanan Penyakit Diabetes Mellitus/ Hipertensi

Adanya riwayat keluarga yang menderita diabetes/ hipertensi lebih 
banyak diungkapkan oleh peserta prolanis di Puskesmas I Denpasar Barat menjadi salah satu faktor yang memicu peserta untuk ikut serta dalam kegiatan prolanis karena efek dari penyakit tersebut sudah dilihat secara nyata oleh peserta

Temuan penelitian ini sejalan dengan penelitian yang dilakukan oleh Fatmawati (2010) menyatakan bahwa terdapat hubungan riwayat keluarga dengan kejadian diabetes/hipertensi, dimana responden dengan riwayat keluarga yang memiliki kejadian diabetes/hipertensi berisiko $10 \%$ lebih besar dibandingkan dengan yang tidak memiliki riwayat kejadian diabetes/hipertensi. Sehingga timbul niat dari peserta untuk mengurangi dampak dari penyakit diabetes/ hipertensi dengan aktif dalam kegiatan prolanis.

Lain halnya dengan persepsi kerentanan yang diungkapkan peserta prolanis di Puskesmas II Denpasar Timur yang dominan karena riwayat pola makan yang beresiko, kebiasaan mengkonsumsi makanan yang beresiko tinggi berpeluang tiga kali lebih besar memiliki kadar gula darah yang tidak terkontrol (Wicaksono,2011). Namun efek dari penyakit tersebut belum dirasakan/ dilihat langsung oleh peserta yang menjadi salah satu faktor kurang tertariknya peserta dalam kegiatan prolanis.

2. Persepsi Peserta BPJS Kesehatan Terhadap Tingkat Keseriusan Penyakit Diabetes Mellitus/ Hipertensi

Tingkat keseriusan penyakit diabetes/ hipertensi menimbulkan kecemasan dan ketakutan pada peserta prolanis. Kecemasan dan ketakutan yang dirasakan peserta prolanis di Puskesmas I Denpasar Barat karena adanya pengalaman keluarga atau riwayat kesehatan dari peserta prolanis yang sudah merasakan dampak dari penyakit diabetes/hipertensi yang berpengaruh pada kualitas hidup penderita.

Temuan ini sejalan dengan penelitian Sudana \& Dewi (2013) kualitas hidup lansia secara umum dengan normotensi baik yaitu dengan persentase $57.1 \%$. Sedangkan pada responden lansia dengan hipertensi, kualitas hidup lansia secara umum didapatkan buruk yaitu dengan persentase $56,7 \%$

Sedangkan di Puskesmas II Denpasar Timur menunjukkan tingkat keseriusannya berdampak pada organorgan tubuh. Hal ini diungkapkan berkaitan dengan tingkat kecemasan informan terhadap gangguan akibat efek obat yang diminum pada penderita diabetes/ hipertensi sehingga peserta tidak patuh minum obat.

Ketidakpatuhan pasien diabetes mellitus minum obat disebabkan karena kurangnya pengetahuan mengenai manfaat obat/terapi sehingga pasien tidak sepenuhnya patuh melaksanakan anjuran pengobatan. Penelitian Boyoh dkk (2015) menunjukan bahwa hubungan pengetahuan berpengaruh terhadap kepatuhan minum obat penderita diabetes mellitus tipe 2

3. Manfaat yang diperoleh Peserta BPJS Kesehatan selama Mengikuti Program Prolanis

Manfaat yang dirasakan peserta prolanis di Puskesmas I Denpasar Barat 
tidak hanya adanya perubahan pada kontrol gula darah atau perubahan pada fisiknya tapi lebih pada manfaat sosial. Dengan adanya program prolanis penderita diabetes/ hipertensi bisa bertemu dengan teman baru, sharing seputaran penyakit dan hal lainnya dan peserta tidak merasa kesepian karena ada teman yang diajak berbagi.

Sharing atau saling bertukar informasi diperlukan penderita penyakit kronis. Dengan adanya program prolanis penderita penyakit kronis mempunyai perkumpulan yang formal dan bermanfaat bagi penderita sendiri. Penderita bisa bertemu dengan temanteman sependeritaan dan saling berbagi informasi sehingga menumbuhkan motivasi/ semangat untuk tetap sehat, penderita mampu mengelola penyakitnya secara mandiri sehingga penderita penyakit kronis memiliki kualitas hidup yang baik.

Sedangkan manfaat yang dirasakan peserta prolanis di Puskesmas II Denpasar Timur dominan pada perubahan gula darah. Rendy \& Margareth (2012) menyatakan tujuan utama diabetes mellitus adalah mencoba menormalkan aktivitas insulin dan kadar glukosa darah dalam upaya mengurangi terjadinya komplikasi vaskuler serta neuropatik. Namun peserta kurang merasakan adanya dukungan sosial dari peserta lainnya. Manfaat yang dirasakan lebih pada dampak kesehatan individu.

4. Hambatan yang dialami Peserta BPJS Kesehatan selama Mengikuti Program Prolanis

Berdasarkan hasil penelitian terhadap persepsi hambatan peserta prolanis selama mengikuti kegiatan prolanis menunjukkan bahwa peserta prolanis di Puskesmas I Denpasar Barat mengalami hambatan karena hambatan individu/ peserta sendiri, peserta tidak mengalami kesulitan berkaitan dengan waktu pelaksanaan prolanis karena peserta dominan sudah pensiun serta jadwal pelaksanaan kegiatan prolanis sudah di atur dengan baik.

Hambatan yang dialami peserta prolanis di Puskesmas II Denpasar Timur lebih bervariasi, selain hambatan tersebut berasal dari individu/ peserta prolanis hambatan yang dirasakan terkait jadwal pelaksanaan senam yang dilaksanakan puskesmas tidak konsisten Salah satu peserta prolanis di Puskesmas II Denpasar Timur menyatakan kesulitan dalam mengikuti kegiatan prolanis karena berbenturan dengan pekerjaan. Penelitian ini sejalan dengan penelitian yang dilakukan Wahyuni dkk (2016) pekerjaan menjadi salah satu hambatan lansia untuk berpartisipasi ke posyandu lansia. Responden yang bekerja berpeluang 97,154 kali lipat untuk tidak berpartisipasi dalam kegiatan pembinaan kesehatan dibandingkan dengan responden yang tidak bekerja. Sehingga diperlukan komitmen yang kuat dari peserta untuk meningkatkan status kesehatannya

5. Cues to action Peserta Prolanis dalam Mengikuti Kegiatan Prolanis

Dari hasil penelitin terhadap isyarat untuk bertindak dari peserta prolanis dalam mengikuti kegiatan prolanis seperti sikap petugas yang ramah 
diperlukan dalam memberikan pelayanan, petugas dalam hal ini dituntut lebih sabar karena peserta prolanis lebih banyak yang berusia lanjut sehingga membutuhkan perhatian dan kesabaran yang mampu memotivasi peserta untuk datang kembali.

Penelitian ini sejalan dengan penelitian yang dilakukan Rifnaehi (2017) bahwa peserta aktif datang mengikuti kegiatan prolanis karena petugas kesehatan yang memberikan pelayanan dengan ramah sehingga peserta merasa termotivasi untuk aktif dalam kegiatan prolanis.

Selain itu dukungan yang diperlukan tidak hanya dari petugas tetapi dari sesama peserta prolanis. Dukungan berupa motivasi dari peserta lainnya akan membuat peserta tidak sendiri merasakan sakit, peserta memiliki semangat untuk tetap sehat walaupun menderita penyakit kronis.

Woodhworth mengungkapkan bahwa perilaku terjadi karena adanya motivasi atau dorongan yang mengarahkan individu untuk bertindak sesuai dengan kepentingan atau tujuan yang ingin dicapai. Karena tanpa dorongan tadi tidak akan ada suatu kekuatan yang mengarahkan individu suatu mekanisme timbulnya perilaku. Dorongan diaktifkan oleh adanya kebutuhan (need) dalam arti kebutuhan membangkitkan dorongan dan dorongan ini pada akhirnya mengaktifkan atau memunculkan mekanisme perilaku.

Namun motivasi yang diberikan peserta lainnya di Puskesmas II Denpasar Timur belum mendapat respon yang baik sehingga mempengaruhi tingkat partisipasi peserta prolanis.

Upaya lain yang dilakukan Puskesmas I Denpasar Barat untuk meningkatkan partisipasi peserta prolanis adalah dengan membuat inovasi. Inovasi yang dilakukan Puskesmas I Denpasar Barat berhasil menarik keikutsertaan peserta prolanis untuk hadir dalam kegiatan prolanis hal ini terlihat dari meningkatnya jumlah kepesertaan peserta prolanis yang kini sudah dibedakan antara klub prolanis penderita diabetes mellitus dan klub prolanis untuk penderita hipertensi.

Penelitian ini juga sesuai dengan penelitian yang dilakukan Anggraeny (2013) di Puskesmas Jagir Surabaya, untuk meningkatkan kualitas pelayanan Puskesmas Jagir melakukan inovasi dalam hal produk/ jasa dan inovasi proses. Dampak inovasi yang dilakukan terlihat dari meningkatnya jumlah kunjungan pasien setiap tahunnya selain itu inovasi yang dilakukan berdampak pada prestasi-prestasi yang dimiliki Puskesmas Jagir.

Inovasi yang dilakukan Puskesmas I Denpasar Barat selain untuk meningkatkan kualitas pelayanan puskesmas, inovasi yang dilakukan terkait dengan sistem pembiayaan kapitasi yang diterapkan oleh BPJS Kesehatan. Pada indikator komitmen pelayanan ada indikator terkait pelaksanaan prolanis, dimana semakin banyak kepesertaan dan kehadiran peserta prolanis dalam mengikuti kegiatan prolanis maka semakin besar pula dana kapitasi yang diperoleh oleh 
puskesmas tersebut.

Penelitian Ridwan

menyebutkan dana kapitasi program jaminan kesehatan nasional dapat mempengaruhi kinerja petugas kesehatan di Puskesmas berbeda dengan hasil penelitian Eldayana (2015) insentif dana kapitasi jaminan kesehatan nasional tidak ada hubungannya dengan motivasi kerja pegawai Puskesmas Metro tahun 2014.

Puskesmas II Denpasar Timur belum mempunyai inovasi untuk meningkatkan partisipasi peserta prolanis karena pemegang program prolanis belum menemukan gagasan yang tepat untuk meningkatkan partisipasi peserta prolanis, selain itu pemegang program belum pernah melakukan evaluasi terkait program prolanis sehingga belum mengetahui jenis inovasi yang akan diselenggarakan.

\section{SIMPULAN DAN SARAN}

Peserta prolanis di Puskesmas I Denpasar Barat dan Puskesmas II Denpasar Timur merasa rentan terkena penyakit diabetes/ hipertensi. Namun dampak penyakit tersebut menimbulkan ketakutan dan kecemasan pada peserta prolanis di Puskesmas I Denpasar Barat karena efek keseriusan penyakit sudah dilihat/ dirasakan. Sehingga menumbahkan kesadaran peserta untuk mengurangi dampak tersebut dengan mengikuti program prolanis.

Sedangkan persepsi keseriusan peserta prolanis di Puskesmas II Denpasar Timur efeknya tidak dilihat langsung oleh peserta, hal ini terkait persepsi kerentanan dominan karena riwayat pola makan beresiko yang efeknya belum terlihat.

Besarnya manfaat yang dirasakan mampu menutupi hambatan yang dialami, selain itu dukungan teman dan rasa kekeluargaan yang erat meningkatkan partisipasi peserta prolanis untuk berpartisipasi dalam kegiatan prolanis. Hal ini tidak dialami peserta prolanis di Puskesmas II Denpasar Timur peserta lebih merasakan manfaat prolanis yang berdampak pada kesehatannya sendiri.

Dukungan teman dan sikap petugas yang ramah mampu menarik minat peserta prolanis untuk hadir dalam kegiatan prolanis. Tetapi dukungan teman yang diberikan sesama peserta prolanis di Puskesmas II Denpasar Timur belum mampu memotivasi peserta peserta untuk hadir dalam kegiatan. Hal ini terjadi karena kurangnya rasa kebersamaan dan kekeluargaan diantara peserta lainnya.

Maka dari itu puskesmas yang rasio kunjungan prolanis rendah perlu mengundang keluarga yang menderita diabetes/ hipertensi untuk memberikan testimoni untuk merangsang keaktifan peserta prolanis untuk datang dalam kegiatan prolanis, dimana peserta bisa berbagi pengalaman dan menumbuhkan keakrabat dengan peserta lainnya.

\section{DAFTAR PUSTAKA}

Anggraeny, C. (2013). Inovasi Pelayanan Kesehatan dalam Meningkatkan Kualitas Pelayanan di Puskesmas Jagir Kota Surabaya. Kebijakan dan Manajemen Publik 1 (1) : januari 2013 
Boyoh, M, dkk. (2015). Hubungan Pengetahuan dengan Kepatuhan Minum Obat pada Pasien Diabetes Mellitus Tipe 2 di Poliklinik Endokrin Rumah Sakit Prof. DR.R.D. Kandon Manado. E-journal Keperawatan (ekp) 3 (3) : agustus 2015

BPJS Kesehatan. (2014b). Panduan Praktis Pelayanan Kesehatan.http://bpjskesehatan.go.id/bpjs/dmdocuments/04 55038740193d957326594ea0d87b5e.p $d f$ (accessed: 2017, Januari 27)

Eldayana, Susi. (2015). Hubungan Insentif Dana Kapitasi Jaminan Kesehatan Nasional (JKN) dengan Motivasi Kerja Pegawai Puskesmas Metro Tahun 2014. Jurnal Kesehatan Holistik 9 (2) : 64-70

Rendy \& Margaret. (2016). Hubungan Pola Aktivitas Fisik dan Pola Makan dengan Kadar Gula Darah pada Pasien Diabetes Mellitus Tipe II di Poli Penyakit Dalam Rumah Sakit Pancuran Kasih Manado. E-journal (e-kp) 3 (1) : februari 2017

Ridwan. (2015). Hubungan Pembagian Dana Kapitasi program Jaminan Kesehatan Nasional (JKN) dan Motivasi Petugas Kesehatan terhadap Tingkat Kinerja di Puskesmas Kopelma Darussalam Banda Aceh. Skripsi Program Pendidikan Kedokteran, Universitas Syiah Kuala Darussalam Banda Aceh

Rifnaehi. (2017). Hubungan Pengetahuan Sikap Petugas Kesehatan dan Dukungan Keluarga terhadap Motivasi Penderita Diabetes Mellitus Mengikuti Kegiatan Prolanis di Wilayah Kerja Puskesmas Kalikajar Kabupaten Wonosobo. Naskah
Publikasi Program S1

Keperawatan Ngudi Waluyo

Wahyuni, Indah, dkk. (2016). Analisis Partisipasi Lansia dalam Kegiatan Pembinaan Kesehatan Lansia di Wilayah Kerja Puskesmas Sekar Jaya Kabupaten Ogan Komering Ula. Jurnal Kesehatan Masyarakat 7 (2): juli 2016

WHO. (2011). Noncommunicable disease country profiles 2011 WHO global report, Geneva. World isEp:Health Organization

Wicaksono, R. P. ( 2011). Faktor-faktor yang Berhubungan dengan Kejadian Diabetes Mellitus Tipe 2 ( Studi Kasus di Poliklinik Penyakit dalam Rumah Sakit Dr. Kariadi). Artikel Penelitian Ilmiah Program Pendidikan Sarjana Kedokteran, Universitas Diponegoro 